\title{
Kitap Değerlendirmesi: Uğur, Seyit Mehmet. Hanefîlerde Mezhep İçi Tercih ve Usûlü (İstanbul: M.Ü. ilâhiyat Fakültesi Vakfı Yayınları, 2019), 374 sayfa. ISBN: 978-975-548-478-5
}

\section{Elif Mazlum *}

Ebû Hanîfe (ö. 150/767) ve ashabının birçok meselede ihtilâf ettikleri bilinmektedir. Buna bir müctehidden zaman zaman aynı meselede farklı görüşlerin rivayet edilmesi ve sonraki Hanefî fakihlerin, bunlara muhalif görüşleri de eklendiğinde mezhep içindeki ihtilâfların boyutları ortaya çıkmaktadır. Değerlendirmesini yaptığımız eser, İslâm hukuku sahasında nitelikli çalışmalar yapan Seyit Mehmet Uğur tarafından, söz konusu ihtilâfların sonucu olarak ortaya çıkan mezhep içi tercih ve usulü problemini çeşitli yönleriyle açıklamak amacıyla yazılmış Hanefi Mezhebinde Mezhep İçi Tercih ve Usûlü̈ başlıklı doktora tezi çalışmasının kitaplaştırılmış halidir. 2019 yılında basılarak okuyucuların teveccühüne sunulan bu eserin adının, tez başlığındaki tekrar eden kelimeden arındırılarak yayımlanması isabetli olmuştur.

Bir giriş, sırasıyla "Mezhep İçi Tercihin Mahiyeti", "Mezhep İçi Tercihin Gerekliliği ve Râcih Görüşün Bağlayıcılığı”, "Mezhep İçi Tercih Usûlünün Mahiyeti” ve "Mezhep İçi Tercih Usûlünün Oluşum Süreci” isimlerini taşıyan dört bölüm ve sonuçtan oluşan kitabın konusu gerek mukallid fakihe yardımcı olması gerekse fetva verirken keyfî hareket edilmesini önlemesi açısından oldukça mühimdir. Bu yönüyle meselenin önemine dikkat çeken yazar, konunun fikıh tarihindeki teori ve uygulamasını açıklığa kavuşturmaya çalışmıştır. Bölümlerin sıralaması incelendiğinde, ilk etapta dördüncü bölümün belki tezin başına alınması gerektiğine dair bir izlenim hâsıl olsa da bu bölümde, hangi fakihin mezhep içi tercihe nasıl bir katkı yaptığı kronolojik olarak sunulmuş ve diğer üç bölüme atıflar yapılarak bütünlük sağlanmıştır.

1 Uludağ Üniversitesi Sosyal Bilimler Enstitüsü, 2017.

\footnotetext{
* Sorumlu Yazar: Elif Mazlum (Arş. Gör.), Yalova Üniversitesi, İslami ilimler Fakültesi, Temel İslam Bilimleri Bölümü, Yalova, Türkiye. E-posta: elif.mazlum@yalova.edu.tr ORCID: 0000-0002-8043-1745 
Müellif çalışmasında, mezhep içi tercihi fürû-1 fikıh cihetinden ele almış, usuldeki tercihleri ise, müstakil bir çalışmada incelenmesi gerektiğini ifade ederek, araştırmanın dışında bırakmıştır. Bununla birlikte Hanefî mezhebindeki ihtilâflı meselelerde, görüşlerden hangisinin râcih olduğunu belirlemek de araştırmanın amaçlarından değildir. Zira yazarın da belirttiği üzere mezhepteki râcih görüşü tayin edebilmek için tercih ehli seviyesinde fakih olmak gerekir. Böylece yapılan çalışmanın sınırları belirlenmiş ve kitap okunurken akla gelebilecek birtakım meselelere neden değinilmediği açılanmıştır.

Müellif klasik kaynaklarda meselenin nasıl ele alındığını, hangi yönleriyle eksik olduğunu ortaya koymuştur. Arapça, İngilizce ve Türkçe literatür değerlendirmesi yaparak konu üzerinde yapılmış modern araştırmaları da bazı yönleriyle eleştiren yazarın, söz konusu eksiklikleri eserinde tamamlama ve özgün bir çalışma yapma iddiasına sahip olduğu görülmektedir. Söz konusu iddianın büyük oranda gerçekleştiği söylenebilse de eserin üçüncü bölümünde ele alınan mezhep içi tercih ilkeleri konusunda, bu ilkelerin kendi içindeki ve birbirleriyle olan hiyerarşisi noktasındaki ihtilâflardan bahsedilmiş ve bu ihtilâflar karşısında tercih ehlinin nasıl bir yol izleyerek görüşler arasında tercih yapacağı net bir şekilde sunulmamıştır. Bu belirsizlik, okuyucuda tercih ehlinin karşılaştı̆̆ı meselede çıkmaza düşeceğine dair bir intibâ bırakmaktadır. Yanı sıra "esahh", "sahih", "bihî yüftâ" gibi tercih lafızlarının mânaları açıklandıktan sonra, mânanın müelliften müellife değişebilme ihtimali bulunduğunun ifade edilmesi de ilgili lafızların göreceli olduğu, dolayısıyla tercih ehlinin bu lâfızların anlamlarını bilerek doğrudan bir neticeye ulaşamayacağı sonucunu ortaya çıkarmaktadır. Bununla birlikte üçüncü bölüm, çalışmanın hedefine ulaştığı asıl bölümdür. Bu bölümde üç ana başlık altında mezhep içi tercih ilkeleri, mezhep içi tercih usulünün gayesi ve muhatabı çeşitli yönleriyle sunulmuştur. Gerek bu bölümde gerekse diğer bölümlerdeki başlıklandırmaların, konunun anlaşılmasını kolaylaştırıcı bir şekilde seçildiğini belirtmek gerekir. Zira bölüm başl1kları, ana ve alt başl1klar altında ele alınan konular, zihinde kolayca bir taslak oluşturulabilecek şekilde tertip edilmiştir.

Ele alınan konu teorik ve tarihî açıdan işlenirken genellikle klasik kaynaklardan istifade edilmiş, özellikle konunun İbn Nüceym (ö. 970/1563), İbn Âbidîn (ö. 1252/1836) ve Kādîhan'ın (ö. 592/1196) eserlerinde açıkça ele alınması sebebiyle, bu müelliflerin çalışmalarına daha çok müracaat edilmiştir. Ayrıca çağdaş dönem araştırmalarında yapılan yorumlara da yeri geldikçe değinilmiş̧ir. Buna mukabil eser içinde bazen konuların asıl kaynaktan aktarılmadığı, hatta nâdiren de olsa kaynaksız bilgilerin bulunduğu da gözlemlenmiştir. Örnek olarak "Hanefîlere göre avâmın müftîler ve görüşler arası tercih yapması evla olmakla birlikte zorunlu değildir" (s. 214) ifadesine yer verildiği ancak bununla ilgili hiçbir kaynak gösterilmediği 
müşahede edilmiştir. Böyle bir durumda öncesinde bu bilgi geçtiyse de o dipnota atıf yapılması daha doğru olacaktır.

Meselenin örnekler üzerinden anlatıldığı kısımlarda; belirli şahıs, eser ve konu sınırlaması yapılmaksızın, mezhep içi tercihin mahiyetinin çeşitli yönlerini tespit etmeye imkân tanıyan örnekler belirlenmeye gayret gösterilmiştir. Bu çerçevede genel olarak örnek çeşitliliğinin bol olduğu ifade edilebilse de özellikle birinci bölümde, İslâm hukukunda vakıf müessesi üzerinden verilen örneklerin tekrar ettiği görülmektedir. Ancak diğer bölümlerde, genellikle çarpıc1 ve günlük hayatta karşılaşılabilen farklı örnekler tespit edilmeye çalışılmıştır.

Tez olmasının doğal sonucu olarak akademik bir üslûpla ele alındığı gözlemlenen kitapta, zaman zaman temel problemler soru sorularak tespit edilmiş ve okuyucunun bu soru etrafında yoğunlaşması sağlanmıştır. Akabinde yöneltilen sorulardan tam olarak neyin kastedildiği açıklanarak cevaplar aranmıştır. Buna mukabil tanımların yer verildiği kısımlarda, akademik çalışmalarda alışılagelmiş olan, önce sözlük sonra terim anlam düzeninin genellikle takip edilmediği görülmektedir. Zira müellif, tanımların yer aldığı kısımlarda çoğunlukla terim anlamını vermekle iktifa etmiştir. Buna karşılık kelimelerin terim anlamları derinlemesine irdelenmiş ve çalışmada söz konusu kelimenin hangi anlamda kullanılacağı anlaşılır bir şekilde belirtilmiştir. Ayrıca bazen fukahanın görüşlerini ifade ederken kullandıkları sözcüklerle neyi kastettiklerine de açıklık getirilmiş ve böylece okuyucunun kafasında oluşabilecek çelişkiler ortadan kaldırılmıştır.

Kitaptaki konuların ele alınış yöntemi, ekseriyetle mesele hakkında klasik kaynaklarda geçen görüş benzerliklerinin ve farklılıklarının gün yüzüne çıkarılarak kronolojik sırayla aktarılması şeklindedir. Görüşlerle ilgili çıkarımlar yapılarak bir sonuca varılmış; bazen bunlardan biri tercih edilmiş bazen de bunlara yeni bir yorum getirilmiştir. Buradan hareketle yazarın konuyla ilgili her görüşe veya meseleye dair fikrini beyan ettiği söylenebilir.

Konuyu ele alış biçiminden de alana hâkim olduğu gözlemlenen yazar, araştırmanın birçok yönüyle önceki çalışmaların tamamlayıcısı olduğunu her firsatta dile getirmiştir. Ancak eserde başka çalışmalarda da görülebilecek bölümlere ayrı ayrı başlıklar açarak genişçe yer verirken, tamamlayıcı ve özgün olduğunu ifade ettiği kısımların bazılarını tek başlık altında topladığı müşahede edilmektedir. Bunun dışında birçok kez bazen metin içinde bazen de dipnotta açılamalar yaparak eleştirilerin önünü almaya çalışmıştır.

Mezhep içi tercih usulünün oluşum sürecinin ele alındığı dördüncü bölümde; bu süreç, tarihsel olarak dört başlık altında incelenmiş ve özellikle İbn Âbidîn'in 
tercih usulünün gelişim seyrindeki önemine dikkat çekilmiştir. Öyle ki İbn Âbidîn'in tercih usulünde bir dönüm noktası olduğuna; bu sürecin İbn Âbidîn'den öncesi ve sonrası şeklinde ayrılabileceğine vurgu yapılmıştır. Nitekim önceki bölümlerde de İbn Âbidîn'in konu üzerindeki etkileri tespit edilmiştir. Ne var ki bu bölümde mezhep içi tercih usulü literatüründe etkili şahıslardan birisi olduğu ifade edilen Gaznevî’nin (ö. 593/1197) görüşlerine, diğer bölümlerde pek de vurgu yapılmamıştır. Okuyucu, Gaznevî’nin literatürdeki yerinin önemini ancak son bölüme geldiğinde anlayabilmektedir.

Genel anlamda kitap, konu sıralamasının anlaşılır olması, fukahanın görüşlerinin yorumlanarak sunulmasıyla bir sonuca varılması ve geniş kaynakçasıyla ciddi bir araştırmanın ürünüdür. Konuyla ilgili derli toplu bir eser olması sebebiyle, hem alana meraklı olanların hem de bu mesele çerçevesinde çalışma yapmak isteyenlerin başvurabileceği bir çalışmadır. Aynı zamanda konuyla bağlantılı eksik görülen alanlara da dikkat çeken eser, yapılabilecek yeni araştırmalara da ışık tutmaktadır. 